\title{
A RESPONSABILIDADE SOCIOAMBIENTAL DA INDÚSTRIA DO PETRÓLEO COMO FORMA DE EFETIVIDADE DA FUNÇÃO SOCIAL DA PROPRIEDADE E DO DESENVOLVIMENTO SUSTENTÁVEL
}

Fabianne Manhäes Maciel

Doutora em Direito pela Universidade do Estado do Rio de Janeiro (UERJ). Professora adjunta na Universidade Federal Fluminense (UFF). Coordenadora do Curso de Direito da UFF em Macaé.

\section{Resumo}

A propriedade urbana deve atender a função social cabendo ao Poder Público a regulamentação de instrumentos urbanos e da instituição de políticas públicas adequadas à efetivação do direito à moradia. Todos os instrumentos previstos para a Política Urbana carecem de vontade política do poder público estabelecendo uma fiscalização adequada somada a uma parceria com as empresas que movimentam a exploração de petróleo nas cidades sede visando uma efetividade de um planejamento urbano adequado. $\mathrm{O}$ que se pretende é a constatação da necessidade de cumprimento da responsabilidade social das empresas do ramo petrolífero, para que seja possível um desenvolvimento urbano adequado, atingindo a acreditada justiça social.

\section{Palavras-chave}

Propriedade; Função social; Responsabilidade social; Petróleo.

\section{Abstract}

Urban property must meet the social function fitting to the Government regulation of urban instruments and public policy institution appropriate to the realization of the right to housing. All the instruments provided for Urban Policy lack of political will of the government establishing adequate monitoring coupled with a partnership with companies that move oil exploration in the host cities aiming at effectiveness of a proper urban planning. The aim is the realization of the need to fulfill the social responsibility of companies in the oil sector, so that an appropriate urban development is possible , reaching the accredited social justice. 


\section{Key words}

Property; Social function; Social responsibility; Oil.

\section{Introdução}

O desenvolvimento das sociedades está intrinsecamente ligado à exploração de recursos naturais, o que por conseqüência acarreta degradação ambiental. A indústria do petróleo e gás natural, assim como qualquer outra deverá constantemente rever sua atuação para minimizar os prejuízos ambientais, até porque existirá devido a sua grande escala de produção e produtos tóxicos ofensivos ao meio ambiente uma responsabilidade ampla e necessária. No entanto, não se pretende aqui debater sobre os riscos ambientais da indústria do petróleo devido à queima deste que é muito agressiva, mas discutir a co -responsabilidade em relaçáo ao crescimento desenfreado das cidades na qual se instalam, descaracterizando locais, estabelecendo ocupação desordenada trazendo inclusive favelização, processo migratório com crescimento populacional e impacto nos serviços urbanos.

Para realizar um debate sobre o impacto da indústria do petróleo e gás natural nas cidades, se faz necessário realizar uma discussão primária sobre a propriedade.

A Constituição da República Federativa do Brasil de 1988 assegura o direito de propriedade, estabelecendo como exigência o atendimento de sua inafastável função social, sendo esta uma imposição jurídica que uma vez dissociada de sua aptidão natural desconfigura o motivo que legitima a garantia e a declaração da propriedade, constituindo abuso de direito.

Para a promoção do controle do desenvolvimento urbano, através da formulação de políticas de ordenamento territorial, foi concedido ao poder público municipal determinar a circunspecção do equilíbrio entre os direitos e interesses individuais e coletivos em relação à destinação dada ao solo urbano.

Nesse contexto, novos instrumentos jurídicos de política urbana têm sido implementados em conformidade com o dinamismo social, dentre os quais pode-se destacar o Estatuto da Cidade, que acrescido às normas constitucionais preexistentes pertinentes à política urbana, efetivará a democratização das funções sociais da cidade em benefício de seus habitantes, propiciando condiçóes razoáveis de habitação, trabalho e lazer.

A execução de tais instrumentos, aditados à efetivação das reformas das ordens jurídicas municipais, impulsiona a devida integração entre planejamento, legislação e gestão urbana, democratizando a legalização plena de uma recente ordem jurídico-urbanística de cunho social, que tem por objeto a regulamentação do direito urbanístico trazida pela Constituição Federal referente ao solo (extensão/espaço) da cidade, sanando através da Lei 10.257/2001 a ausência de norma que garantisse sua eficácia. 


\section{Desenvolvimento}

\subsection{A Tutela Constitucional do Direito de Propriedade e sua Função Social}

A Constituição Federal destina um Capítulo à Política Urbana, no Título referente à Ordem Econômica e Financeira (arts. 182 e 183).

O Princípio da Função Social da propriedade encontra-se inserido após às disposiçôes relativas aos princípios gerais da atividade econômica, que, em sendo urbana a propriedade, só se efetiva quando atende às exigências essenciais de ordenação da cidade exaradas no Plano Diretor, art. 182, CRFB/88. ${ }^{1}$

O objetivo principal possui natureza social, tendo como finalidade imediata "viabilizar a democratização das funções sociais da cidade em proveito de seus habitantes, prevendo mecanismos de promoçáo do adequado aproveitamento do solo urbano". ${ }^{2}$

$\mathrm{O}$ art. 183, por sua vez, estabelece a usucapião especial de pequenas áreas urbanas, salientando que a utilização deve ser com a finalidade de moradia. ${ }^{3}$ Contudo, o texto normativo constitucional requer expressamente a produção de uma norma infraconstitucional, qual seja: Lei $\mathrm{n}^{\circ}$. 10.257, de 10.07.2001 - Estatuto da Cidade -, determinando em seu exórdio que "regulamenta os arts. 182 e 183 da Constituição Federal estabelece diretrizes gerais da política urbana e dá outras providências". ${ }^{4}$

O Estatuto da Cidade não tem como único propósito assegurar a execução dos dispositivos constitucionais que disciplina, tendo também o condão de fixar deveres e proibiçóes a particulares e a agentes públicos, renovar a ordem jurídica e institutos jurídicos, estabelecer sançóes para os que transgredirem os preceitos por ela fixados, além de exigir a produção de normas, no âmbito municipal, que garantam a sua total aplicabilidade.

A análise da Lei no 10.257/2001 - Estatuto da Cidade - impóe a junção de normas e princípios constitucionais, a fim de explicitar a real acepção e o alcance de cada um dos seus mandamentos.

1 OSORIO, Letícia Marques. Estatuto da cidade: novas perspectivas para as cidades brasileiras. Porto Alegre: Sergio Antonio Fabris Editor, 2002. p. 8.

2 LOUREIRO, Francisco Eduardo. A propriedade como relaçấo juridica complexa. Rio de Janeiro: Renovar, 2003. p. 27.

3 BRASIL. Tribunal de Justiça do Estado do Rio de Janeiro (4. Câmara). Civil "USUCAPIÁO URBANO -Previsão na Constituição Federal, no Código Civil e no Estatuto da Cidade. - Inocorrência dos requisitos da boa-fé e justo título nesta modalidade de usucapião. - Presença dos requisitos necessários por parte da autora: posse inconteste e ininterrupta por 05 (cinco) anos, área inferior a $250 \mathrm{~m} 2$, inexistência de outra propriedade urbana ou rural por parte da usucapiente. - Inaplicabilidade do art. 2.028 do novo Código Civil, por não tratar a hipótese de usucapião ordinário. - Notificação extrajudicial que não tem o condão de interromper o lapso prescricional de 05 (cinco) anos, diante do inciso V do art. 202 da atual Lei Civil. Usucapiấo que se declara a favor da autora, mantendo-se a gratuidade de justiça. - PROVIMENTO DO RECURSO” APELAÇÃO CÍVEL no. 2006.001.31579. Relator: Desembargador Sidney Hartung. Rio de Janeiro, 14 de novembro de 2006. Disponível em: <http:/www.tj.rj.gov.br>. Acesso em: 15 out. 2007.

4 DALLARI, Adilson Abreu. Estatuto da cidade, São Paulo: Malheiros, 2002. p. 28. 
Nesse diapasão, o Preâmbulo da Constituição Federal de 1988, demonstra que o Estado Democrático de Direito está "destinado a assegurar o exercício dos direitos sociais e individuais, a liberdade, a segurança, o bem-estar, o desenvolvimento, a igualdade e a justiça como valores supremos de uma sociedade fraterna" ${ }^{5}$

Constata-se que, ao elencar os direitos a serem resguardados, o primeiro a ser exposto diz respeito aos direitos sociais, dentre os quais se destaca o direito à moradia, expressamente introduzido ao texto do art. $6^{\circ}$ da Carta Magna, pela redação da Emenda Constitucional no. 26, de 14.02.2000.

$\mathrm{O}$ direito à moradia é referendado pelo art. 70, IV, CRFB/88 ao integrar o dispositivo que concerne aos direitos dos trabalhadores urbanos e rurais, relativos às suas necessidades vitais e às de sua família, devendo ser respeitado sob pena de ferir o principal fundamento que rege a República Federativa do Brasil: a dignidade da pessoa humana, art. 1\%, III, CRFB/88; e um dos seus objetivos fundamentais: a erradicação da pobreza e da marginalização e a redução das desigualdades sociais e regionais, art. $3^{\circ}$, III, CRFB/88. ${ }^{6}$

$\mathrm{O}$ art. $5^{\circ}$ ao dispor sobre os direitos e deveres individuais e coletivos caracteriza alguns como invioláveis (inciso XI), reconhecendo solenemente que a casa (moradia) é asilo inviolável do indivíduo, e que a propriedade atenderá à sua função social (inciso XXIII), o que é reiterado por outros preceitos constitucionais. (v.g., art. 170, III, CRFB/88)

$\mathrm{O}$ art. 23, IX, CRFB/88, determina ser de competência comum da União, dos Estados, do Distrito Federal e dos Municípios a promoção de programas de construção de moradias e a melhoria das condições de habitação e de saneamento básico. ${ }^{7}$

Neste sentido, sob a égide do sistema constitucional brasileiro, verifica-se que a Lei Maior exige a implementação de políticas sociais ativas, e que o Estatuto da Cidade vem viabilizar a materialização do conteúdo constitucional, dando a intensidade necessária para garantir a sua efetividade.

Os instrumentos jurídicos de política urbana, como as leis reguladoras do parcelamento do solo urbano, as leis de zoneamento, códigos de edificação ou utilização compulsórios da propriedade urbana, e outros regulamentos de caráter urbanístico e de preservação do meio ambiente têm sido insuficientes para a resolução dos problemas referentes às cidades e aos pólos urbanos. ${ }^{8}$

Em desacordo com a atual ordem jurídica, destacam-se o elevado preço do solo urbano, a ocupação desenfreada e deterioradora do meio ambiente, especialmente pelas

\footnotetext{
5 Idem.

6 MORAIS de, Alexandre. Direito constitucional. 20. ed. São Paulo: Atlas, 2006. p. 748.

7 LOUREIRO, Francisco Eduardo. A propriedade como relação jurídica complexa. Rio de Janeiro: Renovar, 2003. p. 34

8 Idem.
} 
populações de baixa renda destinados à periferia por diversos fatores, a especulação imobiliária, e a grande quantidade de área não utilizada, ou sua utilização de forma imprópria, sendo certo que ignoram a determinação de atendimento à função social da propriedade. ${ }^{9}$

Desta forma, referir-se à habitação, moradia, casa e lar, é tanger em necessidades básicas do ser humano, asseguradas pela Constituição da República como direito social, sobretudo com o objetivo a que se destina, de indiscutível relevância pública, determinando ao legislador e aos administradores públicos que se produza densidade normativa e implementaçóes políticas, que garantam a máxima eficácia.

No entanto, para se efetivar uma moradia digna, necessário se faz discutir o cumprimento da função social desta propriedade que servirá de moradia.

A Constituição Federal de 1988 reitera o direito à propriedade privada e à sua função social pautando-os dentre os direitos fundamentais, consolidados no art. $5^{\circ}$, incisos XXII e XXIII.

Em seu Título VII, a Carta Magna, ao versar sobre a Ordem Econômica e Financeira, estabelece como fundamento a valorização do trabalho humano e a livre iniciativa, sendo sua finalidade precípua a garantia da existência digna, respeitados os ditames da justiça social, ressaltando que se deve observar os princípios da propriedade privada, art. 170 , inciso II, e, da função social da propriedade, art. 170, inciso III. ${ }^{10}$

O direito à propriedade é propagado em múltiplos dispositivos da Carta Maior: art. $5^{\circ}$, caput, assegura a inviolabilidade do direito à propriedade no mesmo patamar dos direitos fundamentais (vida, liberdade, igualdade e segurança); art. 5\% inciso XXIV, dispóe sobre o procedimento de desapropriação por necessidade ou utilidade pública, ou interesse social; art. $5^{\circ}$, inciso XXV, prescreve sobre a requisição de propriedade particular em caso de iminente perigo público; o art. $6^{\circ}$, com redaçáo trazida pela Emenda Constitucional $n^{\circ} .26$, assevera a moradia como um direito social, e os arts. 182 e 183 regulamentam a política urbana, com alusão à função social da propriedade e à usucapião especial. ${ }^{11}$

Ao inserir a propriedade como uma liberdade fundamental, relacionada ao interesse social e a valores da ordem econômica, a Constituição da República de 1988, numa congregação de Cartas meramente liberais e de propensão social, abduziu modelos como as Constituiçôes italiana e portuguesa, que se restringiam a abordar o tema nos capítulos das relaçóes econômicas. ${ }^{12}$

9 RIBEIRO, Luiz César de Queiroz. O futuro das metrópoles: desigualdades e governabilidade. Rio de Janeiro: Revan, 2000. p. 319.

10 BONIZZATO, Luigi. Propriedade urbana privada \& direitos sociais. Curitiba: Juruá, 2007. p. 103.

11 MORAIS de, Alexandre. Direito constitucional. 20. ed. São Paulo: Atlas, 2006. p. 748.

12 SILVA da, José Afonso. Curso de direito constitucional positivo. 6. ed. São Paulo: Revista dos Tribunais, 1990. p. 241. 
Verifica-se a contumácia do legislador ao aventar a propriedade, contudo, não obstante os irrefutáveis progressos, a expressão "propriedade" repercute-se em dispositivos aparentemente paradoxais. Embora enfatize o seu caráter sacro e infringível em alguns artigos em outros define a essencialidade de sua funcionalização, acoplados a outros princípios e direitos fundamentais. Gustavo Tepedino, amparado em sólida doutrina italiana, ensina que não há mais um motivo para se falar em conteúdo mínimo, como se existisse "antinomia entre a relação de propriedade e o interesse social, mas sim em novo e preciso conteúdo da propriedade, inserida na relação concreta e impregnada dos outros valores não-proprietários tutelados pela Carta Política” ${ }^{13}$ Neste sentido, finaliza Pietro Perlingieri lecionando que, "embora não possa a propriedade privada ser esvaziada, como se fosse um mero título de nobreza, não há um conteúdo mínimo a ser preservado, mas sim vários conteúdos mínimos, relativos a cada estatuto proprietário, a serem individualizados em cada situação." ${ }^{14}$.

A Constituição Federal determinou inúmeros estatutos para distintas posições proprietárias, embasando-se na condição do bem se urbano ou rural; quanto à sua aptidão econômica, produtivo ou improdutivo; e quanto ao critério subjetivo, se o titular é brasileiro ou estrangeiro, sendo certo que nem todas elas usufruem do mesmo prestígio legal.

Inovadoramente, a função social da propriedade além de fixar-se como direito fundamental, alcançou a condição de princípio regente da ordem econômica. A vasta admissão da função social, que se estende a diversos capítulos da Carta Magna, consente em vinculação mais ampla, diretamente atrelada ao fundamento da dignidade da pessoa humana, e à justiça social. ${ }^{15}$

Mesmo estando prevista entre os direitos individuais a propriedade não poderá ser consagrada um como direito individual, "relativizando-se seu conceito e significado, porque os princípios da ordem econômica são preordenados à vista da realização de seu fim de assegurar a todos existência digna, conforme os ditames da justiça social”. ${ }^{16}$

Por fim, importante salientar que, a Constituição Federal convergindo com outras Cartas modernas conferiu ao princípio da função social da propriedade operabilidade, determinando parâmetros e instituindo sançôes aplicáveis em casos de sua inobservância.

13 TEPEDINO Gustavo. Contornos constitucionais da propriedade privada. Temas de direito civil. 3. ed. Rio de Janeiro: Renovar, 1999. p. 275.

14 PERLINGIERI, Pietro. Perfis do direito civil: introdução ao direito civil constitucional. Tradução Maria Cristina de Cicco. 1. ed. Rio de Janeiro: Renovar, 1999. p. 231.

15 OSORIO, Letícia Marques. Estatuto da cidade: novas perspectivas para as cidades brasileiras. Porto Alegre: Sergio Antonio Fabris Editor, 2002. p. 17.

16 SILVA da, José Afonso. Curso de direito constitucional positivo. 6. ed. São Paulo: Revista dos Tribunais, 1990. p. 240. 


\subsection{Direito de Propriedade: Da Política Urbana e Função Social}

O Estatuto da Cidade, em seu art. 4º, elenca um rol exemplificativo de instrumentos disponibilizados ao Poder Público, que tem por escopo organizar os espaços habitáveis e garantir o atendimento à função social da propriedade e da cidade, evidenciando a intervenção urbanística.

Inobstante o entendimento doutrinário, segundo o qual os princípios da função social da propriedade e da função social da cidade contêm positividade e eficácia plena, perante o Poder Judiciário prepondera uma opinião legalista, substanciada na necessidade da subsunção do princípio em normas legais específicas, para a efetiva aplicabilidade desses.

O princípio da função social da propriedade é o conceito que afere coesão e funcionalidade ao conjunto de atos normativos e administrativos que objetivam a adequada constituição dos ambientes habitáveis.

A função social da propriedade consiste na utilização plena do bem, na otimização ou na tendência de otimizar "os recursos disponíveis em mãos dos proprietários ou, então, impondo-se que as propriedades em geral não possam ser usadas, gozadas e suscetíveis de disposição em contradita com estes mesmos propósitos de proveito coletivo". ${ }^{17}$

A Constituição Federal estabelece como competência da União a edição de normas gerais de direito urbanístico, condicionando a ação do Poder Público Municipal, no que se refere ao princípio da função social da propriedade, à promulgação de lei ordinária federal que licencie sua imposição. Entretanto, a lei federal - Estatuto da Cidade - não pode restringir a atribuição outorgada pela Constituiçãao, art. 30, I, e, VIII, não sujeitando o Município a atuação legiferante, tendo a lei federal apenas o condão de descrever alguns instrumentos de política urbana, corroborando para a padronização da nomenclatura e para a uniformização de sua aplicação. ${ }^{18}$

$\mathrm{O}$ art. $4^{\circ}, \$ 1^{\circ}$ do Estatuto da Cidade é conciso ao dispor que os instrumentos mencionados neste artigo regem-se pela legislação que lhes é própria, devendo-se observar o disposto nesta Lei, apresentando instrumentos eficazes, de notável relevância social, assegurando a eficácia do objetivo expressado no art. 182 da Constituição Federal. ${ }^{19}$

O Plano Diretor é o instrumento de política urbana municipal hábil a alcançar o objetivo fundamental do Estatuto da Cidade, no sentido de dar concreção ao cumprimento da função social da propriedade através do implemento do planejamento de recursos urbanísticos.

17 OSORIO, Letícia Marques. Estatuto da cidade: novas perspectivas para as cidades brasileiras. Porto Alegre: Sergio Antonio Fabris Editor, 2002. p. 61.

18 DALLARI, Adilson Abreu. Estatuto da cidade, São Paulo: Malheiros, 2002. p. 311.

19 OSORIO, Letícia Marques. op. cit., p. 62. 
A concepção de Plano Diretor, como ferramenta urbanística, antepóe-se a existência de uma norma geral instituidora das diretrizes necessárias à execução da política urbana.

Inicialmente, indagava-se qual seria o correto instrumento para a edição de um Plano Diretor. Todavia, tal hesitação foi ultrapassada, eis que a Constituição Federal expressamente previu em seu art. 182, $\$ 1^{\circ}$, como competência do Poder Legislativo sua aprovação, sendo, portanto, lei. ${ }^{20}$

Além da mencionada previsão constitucional, outros elementos estão vinculados pela Carta Maior como indispensáveis à composiçáo do conceito de Plano Diretor, quais sejam: o fato de ser um "instrumento básico da política de desenvolvimento e de expansão urbana", a obrigatoriedade para cidades com população excedente a vinte mil habitantes, e, a capacidade de balizar as áreas suscetíveis de cominação de encargos urbanísticos ao proprietário de "solo urbano não edificado, subutilizado ou não utilizado". ${ }^{21}$

Muito embora haja presciência constitucional referente ao tema, durante um lapso temporal manteve-se um espaço para acepçóes normativas mais precisas, anteriores a atuação pormenorizada do legislador municipal na composição do Plano Diretor. Contudo, tal lacuna foi superada com a edição da legislação federal, denominada "Estatuto da Cidade".

O Estatuto da Cidade aditou elementos essenciais ao conceito jurídico de Plano Diretor: o elegeu como instrumento jurídico para categorizar e fundir o sentido de função social da propriedade urbana, ao exprimir em seu art. 39 que a propriedade urbana alcança o cumprimento de sua função social quando atende às exigências fundamentais de ordenação da cidade expressas no Plano Diretor; programou sua determinação como instrumento básico da política de desenvolvimento e expansão urbana, pré-estabelecido pela Constituição em seu art. 182, $\$ 1^{\circ}$, sendo reiterado pelo art. 40 do Estatuto da Cidade, o qual forneceu viabilidade prática; atrelou a efetivação dos instrumentos de implementação de uma política urbana à presença de um Plano Diretor, como por exemplo, o direito de preempção (art. 25, $\$ 1^{\circ}$ ), a outorga onerosa do direito de construir (arts. 28 e 29), as operaçóes urbanas consorciadas (art. 32, caput), e, a transferência do direito de construir (art. 35, caput), condicionando os instrumentos urbanísticos definidos no Estatuto da Cidade ao prévio planejamento urbano, materializado através do Plano Diretor. ${ }^{22}$

O Plano Diretor foi expressamente incluído como instrumento de implementação de política urbana sob o prisma da planificação geral a ser obedecida pelo Município,

20 OSORIO, Letícia Marques. Estatuto da cidade: novas perspectivas para as cidades brasileiras. Porto Alegre: Sergio Antonio Fabris Editor, 2002. p. 77.

21 DALLARI, Adilson Abreu. Estatuto da cidade, São Paulo: Malheiros, 2002. p. 309.

22 RIBEIRO, Luiz César de Queiroz. O futuro das metrópoles: desigualdades e governabilidade, Rio de Janeiro: Revan, 2000. p. 207. 
diante da ênfase institucional que lhe foi conferida. Sua aplicabilidade justifica-se através do seu caráter cogente, mediante a atuação do Poder Público Municipal, possibilitando a constituição de políticas de investimentos, estabelecida no Estatuto da Cidade à imprescindível introdução das suas normas ao plano plurianual, às diretrizes orçamentárias e ao orçamento anual, conforme disposto no art. $40, \S 1^{\circ}$. Ademais, mesmo que náo houvesse uma previsão expressa no Estatuto da Cidade, esta seria uma implicação lógica, pois para que o Poder Público atue utilizando-se de recursos públicos, ainda que previstos no Plano Diretor, é necessário para ser efetivada, a expressa previsão orçamentária. ${ }^{23}$

No âmbito da abrangência, o Estatuto da Cidade determinou que o Plano Diretor englobaria “o território do Município como um todo", art. 40, $\$ 2^{\circ}$, devendo ser ratificado que a competência deve ser exercida nos limites de atuação do legislador municipal, o qual deve ater-se a aspectos urbanísticos, inclusive quando referir-se à áreas rurais que integram o Município, sob pena de usurpar a competência legislativa exclusiva da União.

No que tange à obrigatoriedade de sua edição a Constituição Federal previu em seu art. $182, \$ 1^{\circ}$, a imposiçáo para as cidades com número de habitantes excedentes a vinte mil. Contudo, esta regra foi ampliada pelo Estatuto da Cidade, fixando a obrigatoriedade também para as cidades que integram as regiôes metropolitanas e aglomeraçóes urbanas, art. 41, II; cidades onde o Poder Público Municipal tenha a pretensão de empregar os instrumentos previstos no art. 182, $\$ 4^{\circ}$ da Constituição Federal, art. 41, III; cidades inseridas nas áreas de especial interesse turístico, art. 41, IV; e as cidades integrantes da área de influência de empreendimentos ou atividades com expressivo impacto ambiental de caráter regional ou nacional, art. $41, \mathrm{~V}$, Estatuto da Cidade. ${ }^{24}$

$\mathrm{O}$ art. 50 do Estatuto da Cidade preconizou que os Municípios que não estejam enquadrados na obrigação prevista nos incisos I e II do art. 41 da Lei 10.257/2001, que não possuam Plano Diretor aprovado na data de entrada em vigor da referida Lei, deveráo aprová-lo no prazo de cinco anos. Desta forma, conclui-se que as cidades previstas nos incisos I e II, do art. 41 receberam o prazo de cinco anos para sua edição e efetivação, e as inseridas nos incisos III, IV e V, do art. 41 devem editar o Plano Diretor imediatamente a condição antevista em lei se efetue.

Uma vez fixado o caráter impositivo ao Plano Diretor para determinadas cidades, sua não edição, sob as condiçôes previstas no próprio Estatuto, implica aos infratores sançóes ordinárias estabelecidas nos regimes jurídicos funcionais aplicáveis às autoridades responsáveis, caracterizando o descumprimento de uma obrigação funcional legalmente constituída. $^{25}$

23 BONIZZATO, Luigi. Propriedade urbana privada \& direitos sociais. Curitiba: Juruá, 2007. p. 112.

24 DALLARI, Adilson Abreu. Estatuto da cidade, São Paulo: Malheiros, 2002. p. 313.

25 BONIZZATO, Luigi. Propriedade urbana privada \& direitos sociais. Curitiba: Juruá, 2007. p. 112. 
Importante destacar que, sob o aspecto institucional, a omissão na elaboração do Plano Diretor origina a privação do Município na possibilidade de utilização dos novos instrumentos urbanísticos disponibilizados pelo Estatuto da Cidade. A inexistência de Plano Diretor impossibilita o Município de exigir do proprietário a efetivação da função social da propriedade, uma vez que é sua competência, como lei introdutória de normas básicas de planejamento urbano, mapear a cidade e recomendar o campo de cumprimento do princípio da função social da propriedade, através da materialização e da aderência dos projetos para a realidade urbana idealizados.

Salutar que, como mecanismo básico da política de expansão urbana, o Plano Diretor pode fixar as orientaçóes basilares sobre os assuntos de pertinência municipal referentes ao urbanismo. Nesta concepção estáo introduzidos o poder e o dever de apresentar o planejamento de utilizaçáo dos instrumentos da política urbana predispostos aos Municípios, art. $4^{\circ}$ do Estatuto da Cidade, obedecendo-se, entretanto, o limite inerente a qualquer planejamento, não podendo conjeturar especificidades característicos de normas de elaboração e execução. Destarte, inexiste conteúdo relacionado ao planejamento urbano que não tenha sido abordado na esfera de alcance do Plano Diretor. ${ }^{26}$

\subsection{A Ocupação Irregular do Solo e a Não Efetividade dos Instrumentos da Polí- tica Urbana}

A ocupação do espaço urbano brasileiro se faz marcada por déficit habitacional, deficiência de qualidade dos serviços de infra-estrutura, serviços de transporte deficientes e poluentes, agressão ao meio ambiente com ocupação irregular, por exemplo, diminuiçáo da segurança, etc.

Todos os reflexos destas desordens urbanas precisavam ser corrigidas pela urbanificação, mediante a ordenação dos espaços habitáveis - de onde se originou o urbanismo como técnica e ciência, que busca corrigir os desequilíbrios urbanos. Em sua concepção original, o urbanismo era conhecido como a arte de embelezar cidades, porém, recentemente, seu conceito se aproximou de um sentido social, no qual seu objetivo é o bem-estar coletivo, através de uma legislação, de um planejamento e da execução de obras públicas que permitam o desempenho harmônico e progressivo das funçóes urbanas elementares. ${ }^{27}$

A legislação urbanística teve sua primeira delineação com as leis de desapropriação, tendo a primeira sido promulgada em 1826 e autorizava a desapropriação por utilidade pública para a execução de obras de comodidade geral e decoração pública. Desde esta

26 OSORIO, Letícia Marques. Estatuto da cidade: novas perspectivas para as cidades brasileiras. Porto Alegre: Sergio Antonio Fabris Editor, 2002. p. 79.

27 SILVA. Op. Cit., nota 86, p. 27/31. 
primeira legislação, muito se tem evoluído em matéria de legislação urbanística, porém, cabe ressaltar que seu fundamento constitucional não é de longa data, uma vez que mesmo a primeira Constituição da República nada trouxera de interesse em direito urbanístico. ${ }^{28}$

Por seu turno, a Constituição Federal de 1988 ofereceu bastante atenção à matéria urbanística fixando diretrizes ao desenvolvimento urbano (art. 21, XX e 182), tratando da preservação ambiental (art.s 23, III, IV e VII; 24, VII e VIII; e 225), de planos urbanísticos (art. 21, IX; 30, VIII; e 182), além do tratamento à função social da propriedade. O Estatuto da Cidade veio somar oferecendo diretrizes gerais para a política urbana, conforme previsto nos arts. 21, XX, 182 e 183 da Constituição Federal de 1988.

Outra vertente do urbanismo atual é o planejamento, mencionado no ponto 3.1, devendo ser ressaltado que seja a execução e planos urbanísticos nacionais e regionais, fixando a ordenação do território aos planos de desenvolvimento econômico e social (art. 21, IX, Constituição Federal/1988) ou locais, seja o planejamento urbanístico local, mediante controle do uso, do parcelamento e da ocupação do solo urbano (art. 30, VIII, Constituição Federal/1988); estes fazem parte de um processo urbanístico que visa conceder o cumprimento a função social da propriedade.

A Constituição Federal de 1988 preferiu instituir um planejamento urbano não apenas para a manutenção de uma diretriz para alcance de uma cidade ordenada, mas, em sentido mais amplo, proporcionou traçar diretrizes para a satisfação dos próprios interesses coletivos.

Porém, para um planejamento que alcance sua finalidade, não basta sua formulação, mas a fixação do seu real cumprimento a curto, médio e longo prazo. Para que isso ocorra, se faz mister analisar o respeito à função social da propriedade, que por sua vez deve caminhar junto com os interesses coletivos, sem sobrepor-se a eles.

Com o desenvolvimento do processo civilizatório, as necessidades humanas se mostraram ilimitadas, o que ocasionou conflitos no seio da sociedade, tendo sido uma aposta do legislador infraconstitucional a edição da Lei no $10.257 / 2001$, como forma de alcançar a harmonia e solidariedade entre as classes proprietária e não-proprietárias, buscando, principalmente, a ordenação do pleno desenvolvimento das funçóes sócias da propriedade.

Porém, infelizmente, o Estatuto da Cidade não tem conseguido alcançar o fim que se propôs, devendo a sociedade brasileira repensar sua aplicação e visualizar novos caminhos para obter a ordenação urbana necessária para o desenvolvimento do país.

28 Idem, pág. 55-57. 


\subsection{A Indústria do Petróleo como Meio de Desenvolvimento Urbano}

No Brasil, a produção e exploração de petróleo se iniciaram em 1864 quando o imperador D. Pedro I decretou a autorização sob o número 3.352-A, tendo cinco anos mais tarde autorizado os americanos Thomas Denny Sargebt e Edward Pellew Wilson pelo prazo de noventa anos o primeiro e 30 anos o segundo, a extrair turfa, petróleo e outros minerais, à exceção de diamantes, nas comarcas de Camumu, Ilhéus e nas margens do Rio Maraú, na então província da Bahia. ${ }^{29}$

Atraídos pela presença de rochas betuminosas, utilizadas na fabricação de óleo ou gás de iluminação e lubrificantes, diversos interessados solicitaram concessão que envolvia também o carvão para a indústria de transportes, já que na época, o petróleo ainda era novidade. Esta nova perspectiva de exploração acabou por determinar diversos conflitos de terras onde se encontravam as jazidas, sob a alegaçáo dos proprietáros de que eram os verdadeiros descobridores não sendo possível a concessão por outrem.

Até o final do séc XIX, o Brasil ainda era mercado secundário para as grandes companhias, ou sejam um mercado em expansão. Em 1899 a América Latina figurava em terceiro lugar no consumo de derivados de petróleo atrás da Europa e do mercado interno norte-americano.

Na época das primeiras concessôes, os primeiros poços eram rasos com o objetivo de retirada para material de utilização em iluminação. Porém, a preocupação com o petróleo foi determinante na promulgação da Lei de Minas de 1921 e na Constituição de 1934, prevendo a nacionalização das riquezas do subsolo.

Em pleno Estado Novo, Getúlio Vargas assinou o Decreto-lei no 395, de 29 de abril de 1938 que tornava de exclusiva competência do Estado à regulação da produção, importação, refino, transporte, distribuição e comercialização do petróleo no Brasil criando o Conselho Nacional de Petróleo -CNP, sendo órgáo colegiado cujo presidente era nomeado pelo Presidente da República.

Após a segunda guerra mundial o trabalho conjunto de militares brasileiros junto com os americanos cria uma nova realidade com a hegemonia do grupo pró-americano. O Departamento de Estado do governo americano organizou um lobby do Congresso pela alteração das leis protecionistas brasileiras, a favor das distribuidoras estrangeiras. ${ }^{30}$

No entanto, após emendas no projeto de lei sobre pesquisa, lavra, refino e transporte de petróleo foi aprovado em 03 de outubro de 1953, a Lei no 2004 estabelecendo o monopólio para a União e inclusive, a criação da Petrobras para a execução das atividades

29 SANTOS, Sérgio Honorado dos. Royalties do Petróleo à luz do direito positivo: Rio de janeiro: Esplanada, 2002. p. 14

30 PIQUET, Rosélia. Petróleo, royalties e regiâo. Rio de Janeiro: Garamond, 2003. p. 21. 
de implementação das tarefas de exploração e produção de petróleo e delega ao CNP a fiscalização do setor.

Da promulgação da Lei no 2004/53 até hoje muita coisa mudou e a instalação nas pequenas e médias cidades, inclusive na cidade de Macaé, cidade sede da exploraçáo na Bacia de Campos trouxe impactos significativos para o urbanismo. Macaé passou de uma cidade com economia voltada basicamente para a agricultura (cana), pecuária e pesca para uma cidade com alto índice de especulação imobiliária devido a instalação de empresas que direta ou indiretamente precisam sustentar a indústria do petróleo.

A evolução populacional foi absurda acarretando impactos na moradia, mobilidade, infra-estrutura exigida, além de impactos de aumento significativo nos serviços públicos.

Deste modo, não é possível deixar de lado também os impactos negativos gerados pela indústria do petróleo no entorno das cidades e a devida co-responsabildiade desta para com o desenvolvimento pleno e organizado do espaço urbano.

Para isso, deve ser necessário traçar primeiramente a efetividade dos instrumentos de política urbana por parte do Poder Público, estabelecendo a presença e o cumprimento nas legislações municipais das sançóes possíveis em caso de não cumprimento do proprietário do solo urbano náo edificado, subutilizado ou não utilizado pela não promoção do adequado aproveitamento.

Determinar uma fiscalização eficiente é necessária fazendo com que a especulação imobiliária diminua. Impor sançôes como parcelamento e edificação compulsórios, IPTU progressivo no tempo e desapropriação-sanção deveria ser um comprometimento rotineiros com o interesse público.

No entanto, como dito anteriormente cabe também a indústria do petróleo que determinou o mencionado impacto urbano ser responsabilizada para estabelecer maior envolvimento com a população das cidades que estão instaladas, determinando projetos complementares com os governos municipais garantindo um cumprimento a sua responsabilidade social.

Náo cabe às empresas apenas o atendimento ao que é imposto através de licenciamentos ambientais ou legislação. A responsabilidade social da empresa trata-se de um compromisso voluntário em busca de uma sociedade melhor, mais justa, com a adoção de uma gestão responsável em relação aos seus sócios, empregados, fornecedores, consumidores, a comunidade, o meio ambiente, os chamados stakeholders e perpassam o mero cumprimento das obrigaçôes legais contidas no ordenamento jurídico. ${ }^{31}$ Este conceito

31 GUEDES, Fernanda Antunes. A responsabilidade social e ambiental das empresas sob prisma do realismo jurídico. In: Âmbito Jurídico, Rio Grande, XIII, n. 83, dez 2010. Disponível em: http://www. ambito-juridico.com.br/site/index.php?n_link=revista_artigos_leitura\&artigo_id=8757>. Acesso em abr 2014. 
deve ser expandido a adoção de responsabilidade social com o meio urbano visando o desenvolvimento adequado da sociedade nas cidades onde estão instaladas.

Sendo assim, o processo de instalação e funcionamento da indústria do petróleo deve estar conjugada com a co-responsabildiade desta para com a ordenaçáo urbana e a efetiva participação em políticas públicas de conscientização e regularização do solo. $\mathrm{O}$ que se propóe é uma real atuação conjunta entre poder público, indústria do petróleo e sociedade para garantir o direito social à moradia e a conseqüente efetividade da função social à cidade.

\section{Conclusões}

A propriedade sofreu grandes mutaçóes em seu exercício ao longo dos anos. Houve época em que a exclusividade era particularidade inconcebível, pois possuía um caráter coletivo e social, onde o indivíduo concentrava-se no objetivo de subsistência, e, uma vez alcançado, e escassos os recursos naturais, mudava-se em busca de novos meios de sobrevivência, não se atrelando à terra. Posteriormente, o território tornou-se sinônimo de poder, adquirindo a condição de absoluto. Atualmente, a propriedade é garantida como um direito individual, porém sendo, imperioso o atendimento à sua funçáo social.

O direito de propriedade é resguardado constitucionalmente como fundamental, art. 5 , caput da CRFB/88. A Carta Magna destina ainda um capítulo exclusivo à política urbana, dispondo, sobretudo, que a propriedade deve atender a sua função social. A aludida função social somente se efetiva quando atendidas às exigências previstas no Plano Diretor. Trata-se de um direito elementar, ao qual a Constituição da República reitera sua importância ao descrever a moradia como um direito social, além de prever a inviolabilidade da casa (asilo) do indivíduo.

Neste sentido, ao preconizar que a propriedade atenderá sua função social, verificase a preocupação do legislador em assegurar a plenitude deste direito. Diante disto, foi editado o Estatuto da Cidade, que tem como finalidade democratizar as funçóes sociais da cidade em prol dos habitantes, bem como, evidenciar o liame entre direitos e restriçôes impostas a particulares e ao Poder Público, através da aplicação de instrumento de políticas urbanas.

Os instrumentos de política urbana têm por escopo garantir a eficácia do Estatuto da Cidade, impondo sançóes gradativas para resguardar a função social da propriedade definida pelo Plano Diretor para àquelas cidades com mais de 20 (vinte) mil habitantes, conforme salienta o art. 182, $\$ 1^{\circ}$ da Constituição Federal.

O Plano Diretor confere ao Município o planejamento a ser seguido determinando as exigências de ordenação para o cumprimento da função social da propriedade, através 
do parcelamento do solo urbano náo edificado, subutilizado ou náo utilizado, ou em caso de descumprimento, por meio da sujeição ao pagamento de IPTU progressivo no tempo, ou como medida drástica sancionatória à desapropriação.

No entanto, todos os instrumentos previstos para a Política Urbana carecem de vontade política do poder público estabelecendo uma fiscalizaçáo adequada somada a uma parceria com as empresas que movimentam a exploração de petróleo nas cidades sede visando uma efetividade de um planejamento urbano adequado. A partir do momento que as empresas do setor petrolífero tomarem para si a responsabilidade social na adequaçáo do espaço urbano que estáo instaladas, será possível um planejamento conjunto que dará espaço para uma expansáo urbana adequada que garanta um desenvolvimento sustentável.

Desta forma, afirma-se a evolução legal e social com a edição de leis específicas destinadas a proteger a propriedade, ultrapassando os limites do referido direito, estendendose ao precípuo dos fundamentos constitucionais como a Dignidade da Pessoa Humana deve estar aliado a uma realidade prática de vontade política do Poder Público com a instituição de fiscalização adequada e a responsabilidade social das empresas do ramo petrolífero, para que seja possível um desenvolvimento urbano adequado, atingindo a acreditada justiça social.

\section{Referências}

BONIZZATO, Luigi. Propriedade urbana privada \& direitos sociais. Curitiba: Juruá, 2007.

BRASIL. Constituição (1988). Organização dos textos, notas remissivas e índices por Vera Helena de Mello Franco. 7. ed. Sáo Paulo: RT, 2005.

BRASIL. Lei no 10.257, de 10 de julho de 2001. Regulamenta os arts.182 e 183 da Constituição Federal, estabelece diretrizes gerais da política urbana e dá outras providências. Disponível em: <http://www.planalto.gov.br/ccivil_03/Leis/LEIS_2001/ L10257.htm> Acesso em: 16 set. 2007.

CAVALCANTI, Marise Pessoa. Superficie compulsória: instrumento de efetivação da função social da propriedade. Rio de Janeiro: Renovar, 2000.

CORTIANO JÚNIOR, Eroulths. Discurso jurídico da propriedade suas rupturas: uma análise do ensino do direito de propriedade. Rio de Janeiro: Renovar, 2002,

DALLARI, Adilson Abreu. Desapropriação para fins urbanisticos. Rio de Janeiro: Forense, 1981.

DALLARI, Adilson Abreu. Estatuto da cidade, São Paulo: Malheiros, 2002. 
DI PIETRO, Maria Sylvia Zanella. Direito administrativo. 19. ed. São Paulo: Atlas, 2006.

FRANÇA, V. R. Perfil constitucional da função social da propriedade, Brasília, mar. 1999. Disponível em: <http://www.senado.gov.br/web/cegraf/ril/Pdf/pdf_141/ r141-02.pdf>. Acesso em: 16 set. 2007.

GUEDES, Fernanda Antunes. A responsabilidade social e ambiental das empresas sob prisma do realismo jurídico. In: Âmbito Jurídico, Rio Grande, XIII, n. 83, dez 2010. Disponível em: http://www.ambito-juridico.com.br/site/index.php?_link=revista_artigos_leitura\&artigo_id=8757>. Acesso em abr 2014.

GOMES, Orlando. Direitos reais. 10. ed. Rio de Janeiro: Forense, 1988.

GROSSI, Paolo. História da propriedade e outros ensaios, Rio de Janeiro: Renovar, 2006.

LOUREIRO, Francisco Eduardo. A propriedade como relação juridica complexa. Rio de Janeiro: Renovar, 2003.

MATTIETTO, L. Função social e diversificação do direito de propriedade, Rio de Janeiro, jun. 2005. Disponível em <http://www.fdc.br/Arquivo/Metrado/Revistas/ Revista06/Docente/06.pdf> Acesso em: 16 set. 2007.

MELLO de, Celso Antônio Bandeira. Novos aspectos da função social da propriedade. São Paulo: Revista de Direito Público, 1987.

MONTEIRO, Washington de Barros. Curso de direito civil: direito das coisas. São Paulo: Saraiva, 2000.

MORAIS de, Alexandre. Direito constitucional. 20. ed. São Paulo: Atlas, 2006.

OSORIO, Letícia Marques. Estatuto da cidade: novas perspectivas para as cidades brasileiras. Porto Alegre: Sergio Antonio Fabris Editor, 2002.

PEREIRA, Caio Mário da Silva. Instituiçóes de direito civil: direitos reais. Rio de Janeiro: Forense, 1990.

PERLINGIERI, Pietro. Perfis do direito civil: introdução ao direito civil constitucional. Tradução Maria Cristina de Cicco. 1. ed. Rio de Janeiro: Renovar, 1999.

PIQUET, Rosélia. Petróleo, royalties e região. Rio de Janeiro: Garamond, 2003.

RIBEIRO, Luiz César de Queiroz. O futuro das metrópoles: desigualdades e governabilidade. Rio de Janeiro: Revan, 2000.

SANTOS, Sérgio Honorado dos. Royalties do Petróleo à luz do direito positivo: Rio de janeiro: Esplanada, 2002.

SILVA da, José Afonso. Curso de direito constitucional positivo. 6. ed. São Paulo: Revista dos Tribunais, 1990. 
TEPEDINO Gustavo. Contornos constitucionais da propriedade privada. Temas de direito civil. 3.ed. Rio de Janeiro: Renovar,1999.

TORRES, Ricardo Lobo. Curso de direito financeiro e tributário. 13. ed. Rio de Janeiro: Renovar, 2006.

VENOSA, Silvio de Salvo. Direito civil: direitos reais. 4. ed. São Paulo: Atlas, 2004.

WALD, Arnoldo. Curso de direito civil brasileiro: direitos das coisas. 10. ed. São Paulo: Revista dos Tribunais, 1995. 